\title{
Low-cost Container Yard for School-based Restoration Nurseries
}

\author{
Edward W. Bush ${ }^{1,3}$ and Pamela B. Blanchard ${ }^{2}$
}

AdDITIONAL INDEX WORDS. ecological stewardship, automatic irrigation system, tree production

SUMMARY. A small inexpensive (less than $\$ 1000$ ) container yard, measuring $10 \times 10$ ft square, with an automatic irrigation system was designed for schools participating in the Louisiana State University Coastal Roots Program: A School Seedling Nursery Program for Habitat Restoration. Students helped install the container yard on their school site and oversee native plant production through the course of the school year. Teachers and other school staff checked the nursery during summer months to ensure that the irrigation system was working properly and the plants were healthy. Students grew $\approx 1000$ restoration seedlings per year in their container yard. Each year they transplanted their seedlings and grass plugs on trips to habitat restoration sites across Louisiana's coastal zone. Since the inception of the program in $\mathbf{2 0 0 0}$, the students using this container yard design have produced nearly 24,500 trees and shrubs and over $\mathbf{8 0 0 0}$ grass plugs.

$\mathrm{T}$ he Louisiana State University Coastal Roots Program: A School Seedling Nursery Program for Habitat Restoration (LSU Coastal Roots Program) was initiated 1 Jan. 2000 to assist students in Louisiana in developing a positive attitude of stewardship toward Louisiana's coastal resources and to provide a constructive active learning situation in which they can explore strategies for sustaining our coastal ecosystems. School-based nurseries have been constructed for this purpose at 35 public, private, and parochial southern Louisiana schools. Participating teachers represented upper elementary (Grade 3) through high school, and integration of the program was mostly through science classes and extracurricular environmental clubs. Students at participating schools conducted a year-round, ongoing nursery program during which they grew native Louisiana grasses and trees (Table 1) that can be used by students in a hands-on

The authors would like to thank Ann Gray Blanchard for her assistance in guiding the installation of many of the container yards described in this paper.

Appreciation also goes to the Louisiana Sea Grant College Program for providing initial funding of the Louisiana State University (LSU) Coastal Roots Program: A School Seedling Nursery Program for Habitat Restoration.

${ }^{1}$ Associate Professor, Louisiana State University, School of Plant, Soil and Environmental Science, 137 J. C. Miller Hall, Baton Rouge, LA 70803

${ }^{2}$ Assistant Professor, Louisiana State University, Department of Educational Leadership, Policy and Practice, Baton Rouge, LA 70803

${ }^{3}$ Corresponding author. E-mail: ebush@agctr.lsu.edu. restoration planting field trip 9 months later. Integrated with this hands-on aspect of the program, students learned about nursery maintenance, plant growth, and wetland issues such as coastal land loss, the functions and importance of wetlands to southern Louisiana, how wetlands are being restored as well as other restoration and conservation information.

Louisiana is losing coastal marshes and estuaries at an astounding rate, nearly 10 mile $^{2}$ per year (M. Ford, personal communication). Although southern Louisiana residents are keenly aware of this fact, sadly, the state of the marshes came into the national spotlight only recently with the coverage of the devastation wrought by the 2005 hurricanes Katrina and Rita. The LSU Coastal Roots Program was initiated long before these storms and its place as an ecological stewardship project is now more important than ever. The project helped educators guide students in exploring why it is important to take environmental action now and to make decisions that will help sustain what is left of our fragile Louisiana coastal plain and ecosystems.

The concept of the LSU Coastal Roots Program is simple. In early spring, students plant seeds of native plants. They maintain the seedlings over the spring semester. The teacher and school control the container yard and the seedlings during the summer to ensure that the irrigation system is working properly and that the plants are healthy. Late during the next fall semester, students travel with their seedlings to a restoration site in need of their seedlings to re-establish the natural habitat in an area that has been suffering from various types of degradation. During the field trip, students can observe the state of the coast and how their efforts model an active stewardship role that others might emulate. Students return to their schools to begin the whole process once again. There is no published curriculum for the project. Teachers integrate the project into their classes and school activities in ways that are age-appropriate and make sense for their particular subject.

\section{Impact of hands-on learning and school gardens on students}

School gardening and its impact on student achievement and behavior has been documented through a number of studies. Researchers found that garden programs have a positive impact on enthusiasm for learning and standardized test scores in core academic areas (Emekauwa, 2004; Lieberman and Hoody, 1998). Another study found that students participating in a hands-on environmental stewardship program involving a school-based garden showed a significant positive increase in the results on the Children's Attitudes Toward the Environment Scale possibly

\begin{tabular}{llll}
\hline $\begin{array}{l}\text { Units } \\
\text { To convert U.S. to SI, } \\
\text { multiply by }\end{array}$ & U.S. unit & SI unit & $\begin{array}{l}\text { To convert SI to U.S., } \\
\text { multiply by }\end{array}$ \\
\hline 0.4047 & $\mathrm{acre}(\mathrm{s})$ & $\mathrm{ha}$ & 2.4711 \\
0.3048 & $\mathrm{ft}$ & $\mathrm{m}$ & 3.2808 \\
3.7854 & $\mathrm{gal}$ & $\mathrm{L}$ & 0.2642 \\
2.54 & inch(es) & $\mathrm{cm}$ & 0.3937 \\
0.4536 & $\mathrm{lb}$ & $\mathrm{kg}$ & 2.2046 \\
2.5900 & mile $^{2}$ & $\mathrm{~km}^{2}$ & 0.3861
\end{tabular}


Table 1. These tree and grass species have been grown in the Louisiana State University Coastal Roots Program: A School Seedling Nursery Program for Habitat Restoration container yards. ${ }^{\mathrm{z}}$

\begin{tabular}{ll}
\hline Common name & \multicolumn{1}{c}{ Scientific name } \\
\hline Swamp red maple & Acer rubrum \\
Black mangrove & Avicennia germinans \\
Tupelo gum & Nyssa aquatica \\
Bitter panicum & Panicum amarum \\
Seashore paspalum & Paspalum vaginatum \\
Longleaf pine & Pinus palustris \\
Loblolly pine & Pinus taeda \\
Black cherry & Prunus serotina \\
Water oak & Quercus nigra \\
Nuttall oak & Quercus nuttallii \\
Smooth cordgrass & Spartina alterniflora \\
Bald cypress & Taxodium distichum \\
\hline
\end{tabular}

${ }^{\mathrm{z}}$ Each school selects one or two plant species to grow.

indicating that the opportunity to interact with the environment through the project raised their environmental awareness (Karsh, 2005). In his book, Last Child in the Woods, Louv (2006) describes the growing divide between children and the outdoors, "In the space of a century, the American experience of nature has gone from direct utilitarianism to romantic attachment to electronic detachment." Given this detachment, garden programs also serve to increase children's experiences with nature and provide a context in which students can investigate and explore the natural world. Blair (2009) in an evaluative review of the benefits of gardening reports that seven qualitative research studies indicated that students were 1) highly motivated by gardening and excited by the exploratory learning grounded a garden context; 2) showed improved school attitude and pride in the garden and its products and often involved their parents in the project; 3 ) involved in teamwork and community outreach; and 4) involved in environmental stewardship as well as opportunities to use the garden for mathematics and science education activities. Roth (1992) outlines a continuum of stages in the development of environmental literacy progressing from environmental awareness, to concern, to knowledge, and culminating in environmental action. School gardens set the stage for students to become more environmentally literate.

\section{Need for container yard design}

When the LSU Coastal Roots Program was initiated, teachers were planting their seeds in peat pots set out under grow lights in their classrooms. The plants from this first effort were often spindly and fragile, and the surviving seedling count was very low, usually 100 to 150 seedlings per year. To assure student success in germinating their seeds and raising healthy seedlings, several steps were taken. First, the plants were moved outside where they could receive sufficient light and adequate air movement. Second, seeds were planted in plastic seedling cells that fit neatly into a plastic plant stand, making seedling maintenance (watering, fertilizing, culling, and so on) much easier. Third, a protected container yard was devised to provide automatic irrigation, shade (if needed), and protection from vandals.

These three steps helped improve the successful germination rate, on average, $50 \%$ for these initial schools. Available classroom space was at a premium and thus, moving the project outside was an idea welcomed by all the teachers in the project. Another serious problem was solved by the installation of the container yards: maintenance of the seedlings over summer vacation. Most teachers were unwilling to move the nine plant trays to their home over the summer. Thus, already overburdened facility maintenance personnel were asked to water and control the seedlings, which, sadly, meant that students returned to mostly dead plants in the fall. The container yard described in this article, with its automatic batteryoperated irrigation system, meant that the teachers could control their seedlings over the summer every couple of days and that no one had to be asked to water the seedlings daily.

\section{Container yard installation}

The container yard used in the LSU Coastal Roots Program was designed to fit within a $10 \times 10-\mathrm{ft}$ square portable dog kennel (Fig. 1). Dog kennels were purchased from vendors near the school. With permission of the school administration, a location was established that has ready access to water and was located in a protected area of the school grounds to reduce vandalism. Under the direction of LSU Coastal Roots Program staff, students provided the installation labor for their container yard. A $9 \times 9$ - $\mathrm{ft}$ square was painted on the ground to mark where a 6-inchdeep trench was to be dug. Students dig the trench while other students lay out, cut, and glue polyvinyl chloride (PVC) pipe (Schedule 40) to construct the irrigation system (Fig. 2 ). Risers were installed at the four corners of the square and the valve and solenoid timer were installed on a side near the door. The valve and solenoid timer used in the container yard were an Aquanet DC valve (Netafilm USA, Fresno, CA) and a Netafim AquaPro timer, respectively. The irrigation pipes were flushed and the trenches backfilled approximately halfway to cover the pipes. Pea gravel was raked level on the ground inside the container yard to a depth of at least 3 inches. The pea gravel layer improves drainage and acts as a weed barrier for the interior of the yard. A square of ground cloth measuring $12 \times 12 \mathrm{ft}$ was cut and secured over the interior of the yard. Ground cloth staples were placed every 12 inches to secure the ground cloth. The ground cloth acted as a weed barrier and made the yard easier to keep clean of plant debris. The ends of the ground cloth were buried in the trenches with the remaining soil and this was covered with pea gravel so that it was even with the interior of the container yard. The portable dog kennel was erected around the area being careful not to break the irrigation risers and to place the door nearest the solenoid timer. The timer was set and the emitters adjusted to reach the entire area of the enclosure. The kennel door was locked so that unwanted visitors could not enter the yard. A complete list of materials is provided in Table 2.

An optional shadecloth could be installed by adding taut wires across the top of the kennel to provide support for the shadecloth. Plants overwintering in the container yard could be protected by tie-wrapping clear vinyl to the sides and top of the kennel. Several instances of school vandalism required installation of a chain-linked "roof" to the container yard.

Some very successful schools were able to repot their 1-year-old seedlings into $\mathrm{l}$-gal nursery tree pots. 




Fig. 1. A typical Louisiana State University Coastal Roots Program: A School Seedling Nursery Program for Habitat Restoration container yard located at Pierre Part Elementary School, Pierre Part, LA. This depicts the fencing, irrigation system, tree cells, and tree seedlings in a natural setting. Picture courtesy of A.G. Blanchard taken 10 Oct. 2006.

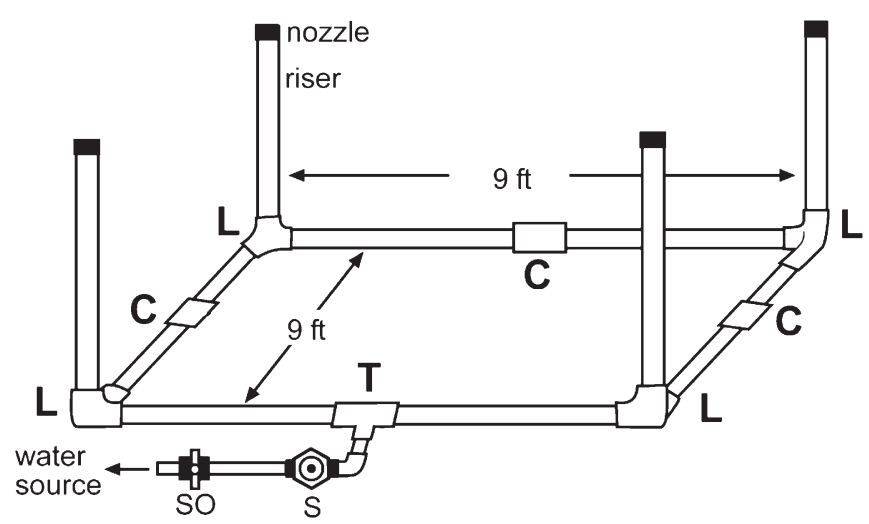

Fig. 2. A diagram of a typical Louisiana State University Coastal Roots Program: A School Seedling Nursery Program for Habitat Restoration container yard irrigation system. Parts can be purchased at most hardware or plumbing supply stores: $\mathrm{C}=$ slip-slip coupler, $\mathrm{L}=90^{\circ}$ slip-slip-thread coupling, $\mathrm{S}=$ solenoid $/$ valve, $\mathrm{T}=$ slip-slip coupling, $\mathrm{SO}=$ shutoff valve $(1 \mathrm{ft}=0.3048 \mathrm{~m})$.

Initially, these tree pots were leaned against the sides of the container yard. A simple stand was devised from PVC pipe to provide a system in which the tall pots could stand upright. This helped with irrigation, fertilization, and seedling maintenance for the seedlings in these tall pots and kept the container yard orderly.

An additional advantage to this container yard design was portability. With relatively little work, unused container yards could be moved to schools on the project's waiting list. The dog kennel could be disassembled and the water shut off. The irrigation risers could be unscrewed and the piping dug up and cut in "half" at the couplers (Fig. 1) so that two risers remained attached on each side (with the timer and backflow preventer still attached to one side). The kennel and the two irrigation halves could be loaded onto a trailer and moved to another school or temporary storage. It was simple to install a relocated container yard at the next location.

\section{Recurring costs and partnerships}

Keeping the cost of the container yard low was important because teachers must find funding to purchase the materials needed to construct the container yard. The cost of materials for the container yard as described previously (with no shadecloth or roof) was $\approx \$ 825$. Reusable seedling plant cells [ultraviolet light-stabilized tree cones (Cone-tainer; Stuewe and Sons, Corvallis, OR)] and plant trays were purchased so that schools could plant 980 plant cells each season. Consequently, the cost was $\approx \$ 175$ to outfit the container yard with planting materials. Both of these expenses were one-time costs with only minimal maintenance and replacement involved. The ongoing expenses of the nurseries were centered on the yearly purchase of seeds, planting media, fertilizer, and water.

New schools were encouraged to identify community partners who could assist with the initial installation and recurring costs for their nurseries. Several schools have successfully written Louisiana Learn and Serve America grants (Louisiana Serve Commission, 2009) and others have applied to state environmental education organizations or private foundations to fund their nursery program. LSU Coastal Roots Program staff provides guidance on running successful nurseries and has regular nursery visitations to troubleshoot plant and/or hardware maintenance issues. New teachers were also given a manual that introduces the concept of stewardship restoration projects, describing the basic decisions that have to be made to implement the project at the school (including funding sources, what to plant, and where to get seeds), describing the process of building a school nursery (with complete instructions and photos) as well as information on how to grow and care for seedlings and how to transplant seedlings at a restoration site (Coleman and Bush, 2002). Nursery information and lessons focused on horticulture principles necessary to running a successful container yard are in the process of being edited for posting to the LSU Coastal Roots Program web site (Blanchard, 2009). These lessons are directly linked to the Louisiana Department of Education Grade Level Expectations (Louisiana Department of Education, 2004) in science so that teachers have the necessary information to integrate the lessons into their teaching curriculum. 
Table 2. Materials and parts list for a container yard installation for a school participating in the Louisiana State University Coastal Roots Program: A School Seedling Nursery Program for Habitat Restoration.

\begin{tabular}{|c|c|c|}
\hline Materials & No. & Description $^{\mathrm{z}}$ \\
\hline \multirow[t]{2}{*}{ Polyvinyl chloride (PVC) pipe (Schedule 40) } & 8 & Pipes cut in 4.5 -ft lengths, 0.75 inch diameter \\
\hline & Unknown & Enough pipe to connect container yard to water source \\
\hline \multirow[t]{4}{*}{ PVC connectors } & 4 & $90^{\circ}$ slip-slip-thread coupler, $0.75 \times 0.5$ inch diameter \\
\hline & 1 & Slip-slip T coupler, 0.75 inch diameter \\
\hline & 2 & $90^{\circ}$ slip-slip coupler, 0.75 inch diameter \\
\hline & 2 & Reducer male adapters, $0.75 \times 0.5$ inch diameter \\
\hline PVC risers (Schedule 80 pipe) & 4 & Threaded on both ends, 3 inches long \\
\hline Water emitters & 4 & With shrub adapters, filters, and low-angle nozzles \\
\hline Solenoid & 1 & $\begin{array}{l}\text { Netafilm AquaPro digital valve timer with cover } \\
\quad \text { (Netafilm USA, Fresno, CA) }\end{array}$ \\
\hline Valve & 1 & Netafim Aquanet direct current valve \\
\hline Valve box & 2 & Valve box, 12 inches diameter \\
\hline Portable dog kennel & 1 & Square portable dog kennel, $10 \times 10 \mathrm{ft}$ \\
\hline Brass (outdoor) gate lock & 1 & Key (make multiple copies of key for staff access) \\
\hline PVC cleaner/cement & 1 & Blue (not clear) PVC cleaner and cement (small can) \\
\hline Tie wraps & 1 & Tie wraps, 3 inches long (to secure riser to rebar) \\
\hline \multicolumn{3}{|l|}{ Optional: } \\
\hline Shadecloth & 1 & $\begin{array}{l}\text { Square piece of shadecloth and fasteners to secure on } \\
\text { top of kennel, } 12 \times 12 \mathrm{ft}\end{array}$ \\
\hline
\end{tabular}

${ }^{\mathrm{z}} \mathrm{l} \mathrm{ft}=0.3048 \mathrm{~m}, \mathrm{l}$ inch $=2.54 \mathrm{~cm}, \mathrm{l} \mathrm{lb}=0.4536 \mathrm{~kg}$.

\section{Program accomplishments}

Since its inception, the LSU Coastal Roots Program has provided a stewardship model that combines classroom science content with handson activities. Each student-run school nursery could produce up to 2000 coastal seedlings each year. These native seedlings have helped stabilize levees and shorelines, reforest coastal habitat, and helped create a black bear (Ursus americanus ssp. luteolus) corridor as well as migratory bird habitats. Restoration plantings have occurred at conservation areas, state and city parks, national wildlife refuges, shorelines, nature preserves, and hurricane protection levees. Nearly 20,500 student-grown plants from 13 shrub and tree species and 8000 plugs from two grass species have been produced and transplanted by participating schools during 88 planting events at 31 different restoration locations. All of these plants were produced using the school-based restoration nursery described in this article. In 2008, 24 schools were participating in the program. With the start of the 2009 and 2010 school years, at least 40 schools will be participating in the program.
The LSU Coastal Roots Program is one of several successful ecological stewardship projects underway at kindergarten through 12 schools in the United States that use nursery production areas of various types. Tampa BayWatch's Bay Grasses in Classes (Tampa BayWatch, 2009) uses small shallow outdoor pools to grow salt marsh grass (Spartina alterniflora). The Weeks Bay National Estuary Program runs similar plant nurseries in Baldwin County, AL, high schools (M. Sedlecky, L. Allen, M. Anderson, and J. Reeves, personal communication). The Maryland Department of Natural Resources and the Chesapeake Bay Foundation's Bay Grasses in Classes (Maryland Department of Natural Resources, 2009) uses indoor aquaria to grow submerged aquatic plants, which include wild celery (Vallisneria americana) and sago pondweed (Stuckenia pectinata). Another project, the University of Wisconsin-Madison Arboretum's Earth Partnership for Schools (University of WisconsinMadison, 2009), has students restoring prairie plants on 1-acre sites on school grounds. Like the LSU Coastal Roots Program, all of these programs integrate the experience of growing and nurturing plants with science content standards that must be met in this age of teaching accountability.

\section{Conclusions}

A simple, functional container yard design for the LSU Coastal Roots Program has helped students managing school-based plant nurseries be successful producers of wetland plants. These schools are working toward the goal of Coast 2050: Toward a Sustainable Coastal Louisiana (Louisiana Coastal Wetlands Conservation and Restoration Task Force and the Wetlands Conservation and Restoration Authority, 1998): to create and sustain habitats, to maintain habitat diversity, and to maintain the exchange of energy and organisms within our coastal environments. By building hands-on experiences, students can become active participants in wetland conservation and become more aware of the environment in which they live (Roth, 1992). Future research planned for this program includes a survey of how teachers integrate the use of the container yard into their lessons and school activities, what students gain 
from 1) growing the plants and 2) transplanting their plants into the environment at their partner restoration site. Research on students' attitudes toward the environment is also planned as is research on the stewardship aspects of the program. It is hoped that this research will help form and guide the program so that students will realize that small actions can have a major impact and that their efforts, both now and in the future, can help shape a positive future for our coastal wetlands.

\section{Literature cited}

Blair, D. 2009. The child in the garden: An evaluative review of the benefits of school gardening. J. Environ. Educ. 40:15-38.

Blanchard, P.B. 2009. LSU Coastal Roots: Seedling nursery program for wetland restoration. 16 Feb. 2009. <http:// coastalroots.lsu.edu>.

Coleman, E.B. and E.W. Bush. 2002. Putting down roots: Starting a seedling nursery for wetland replanting. 25 May
2007. <http://nsgl.gso.uri.edu/lsu/ lsuh02002.pdf $>$.

Emekauwa, E. 2004. They remember what they touch: The impact of place-based learning in East Feliciana Parish. Place-based education collaborative. I Aug. 2004. <http://www. peecworks.org/peec/peec_research/ S0009d4fb-0084fe88>.

Karsh, K.L. 2005. Integrating horticulture biology and coastal environmental issues into the middle school science curriculum. MS thesis, Louisiana State Univ., Baton Rouge, LA. 18 Feb. 2008. $<$ http://etd.lsu.edu/docs/available/ etd-03282005-124326/>.

Lieberman, G.A. and L.L. Hoody. 1998. Closing the achievement gap: Using the environment as an integrating context for learning. 17 Feb. 2009. <http:// www.seer.org/pages/gap.html>.

Louisiana Coastal Wetlands Conservation and Restoration Task Force and the Wetlands Conservation and Restoration Authority. 1998. Coast 2050: Toward a sustainable coastal Louisiana. I June 2007. <http://www.coast2050.gov/ 2050reports.htm>.
Louisiana Department of Education. 2004. Grade level expectations-Science. 16 Feb. 2009. <http://www.doe.state.la. us/lde/saa/1915.html>.

Louisiana Serve Commission. 2009. 2008-09 Learn and Serve America grant guidelines. 16 Feb. 2009. <http://www. crt.state.la.us/laserve/las/documents/ 200809 guidelines.htm>.

Louv, R. 2006. Last child in the woods: Saving our children from nature-deficit disorder. Algonquin Books, Chapel Hill, NC.

Maryland Department of Natural Resources. 2009. Bay grasses in classes. 16 Feb. 2009. <http://www.dnr.state.md.us/ bay $/$ sav $/$ bgic/ $/>$.

Roth, C.E. 1992. Environmental literacy: Its roots, evolution, and directions in the 1990s. Environmental Education, Columbus, $\mathrm{OH}$.

Tampa BayWatch. 2009. Bay grasses in classes. 16 Feb. 2009. <http://www. tampabaywatch.org/index.cfm?fuseaction= content.home\&pageid $=30>$.

University of Wisconsin-Madison. 2009. Earth partnership for schools. 16 Feb. 2009. <http://uwarboretum.org/eps/>. 